\title{
Improving The Students' Vocabulary Mastery Using Snakes And Ladders Game
}

\author{
Atik Prabantari, Abdul Asib, Teguh Sarosa \\ Teacher Training and Education Faculty Sebelas Maret University
}

Email: Aprabantari@yahoo.com

\begin{abstract}
The objectives of the research were to find out whether snakes and ladders game can improve the students' vocabulary mastery and to describe the class atmosphere when the snakes and ladders game is implemented in the class. The research was carried out at elementary school in Karangmojo. The approach used in this research was a classroom action research. It was conducted from May 2014 to June 2014. The subject of the research was the fifth grade of an elementary school in Karangmojo in the academic year of 2013/2014. The researcher collected the data using qualitative and quantitative method. The result of this research showed that the use of snakes and ladders game could improve the students' vocabulary mastery and class atmosphere. The improvement of the students' vocabulary mastery included; the students could understand the meaning of word, pronounce the words correctly, spell the vocabulary correctly, and use the words in appropriate context of situation. The improvement of class atmosphere included; the students' interest toward the material increased, they were active during the lesson, and could work in group and individually. The students' mean scores improved which could be seen from their mean score of pre-test (59.2), post-test 1 in cycle 1 (69.1), and also post-test 2 in cycle 2 (77.6).
\end{abstract}

Keywords: vocabulary mastery, class atmosphere, snakes and ladders game

Tujuan dari penelitian ini adalah untuk mengetahui apakah permainan ular tangga dapat meningkatkan kemampuan pemahaman kosakata siswa dan mendeskripsikan suasana kelas ketika permainan ular tangga di implementasikan di kelas. Penelitian diadakan di sebuah SD di Karangmojo dari bulan Mei 2014 sampai dengan Juni 2014 dengan menggunakan teknik Penelitian Tindakan Kelas (PTK). Subyek dari penelitian ini adalah siswa- siswi kelas V di sebuah SD di Karangmojo di tahun ajaran 2013/2014. Peneliti mengumpulkan data dengan menggunakan metode data kualitatif dan data kuantitatif. Hasil dari penelitian ini menunjukkan bahwa penggunaan permainan ular tangga dapat meningkatkan kemampuan pemahaman kosakata siswa dan suasana kelas. Peningkatan kemampuan pemahaman kosakata siswa meliputi; siswa dapat memahami arti kata, melafalkan kata-kata dengan benar, mengeja kata-kata dengan benar, dan menggunakan kata-kata tersebut dalam konteks kalimat yang tepat. Peningkatan suasana kelas meliputi; minat siswa terhadap materi meningkat, siswa menjadi aktif selama pelajaran, dan dapat bekerja dalam grup dan individu. Nilai rata-rata siswa meningkat dan dapat dilihat dari nilai rata-rata tes mereka. Mereka mendapat 59,2 untuk pre-test; 69,1 untuk post-test 1; dan 77,6 untuk post-test 2.

Katakunci: Kemampuan pemahaman kosakata, situasi kelas, permainan ular tangga 
Learning vocabulary is believed to be the most crucial requirement because it becomes a central part in English learning. Vocabulary refers to a list or set of words for a particular language or a list or set of words that individual speaker of a language might use (Hatch and Brown, 1995: 1). Vocabulary is one of the important language elements should be mastered by the students. By mastering it the students can improve their English and understand the language. The ideal condition of vocabulary mastery from this research is the students can understand the meaning of words, pronounce the words correctly, spell the words correctly, and use the words in appropriate context of situation.

The researcher did preliminary class observation and pre - test to find the problems at the fifth grade of an elementary school in Karangmojo. Based on the pre-test, the researcher got the data of the students' problem. Most of them had difficulties in mastering vocabulary. The indicators are; they have difficulty to memorize the meaning of words, cannot spell the words correctly, have problem in pronouncing the words, and it is hard for them to use the words in appropriate context and situation.

Some factors caused the students had difficulties in vocabulary mastery. The teacher's technique in delivering material is not suitable and interesting. In teaching and learning process, the teacher teaches vocabulary just by reading the material from source book. The classroom situation was not conducive. While learning English some students did not pay attention to the teacher's explanation. They talked with their friend, saw something outside the class, and sometimes made noisy while the teacher was explaining the material. Last, the time and equipment were limited. In an elementary school in Karangmojo, English was taught only 60 minutes every week. The equipment which was also limited. It made the teacher difficult to explore the material.

The researcher proposed one of teaching techniques as the solution in learning vocabularies. The teaching technique which was suitable to solve the problems was snakes and ladders game. It was adjusted to the characteristics of the students in an elementary school which they loved to play a lot. By implementing snakes and ladders game in classroom practice, it was expected that 
this game could induce the students to get involved in the lesson, because it brought the sound of joy and relaxation. Besides, through snakes and ladders game the students could experiment, discover, and interact with their environment.

Vocabulary is one of important skills in a language to achieve the success in language teaching learning process especially English. There are some definitions of vocabulary proposed by some linguist experts. Hornby (1995: 131) says that vocabulary is the total number of words in a language and vocabulary is a list of words with their meaning. Similarly, Hatch and Brown (1995: 1) state that vocabulary is a list or set of words for a particular language or a list or set of words that individual speakers of a language might use. Since vocabulary is a list, the only system involved is alphabetical order in dictionaries. Here, vocabulary is written in alphabetical order in dictionaries based on the system or rule of the foreign language. While Schmitt\& McCharty (1997: 40) argues that vocabulary is a basis of a language; it is very important to be mastered first. People can not speak well and understand written materials if people do not master it. He added that no matter how successfully the sound of the foreign language is mastered, without words to express the wider range of meanings, communication in a foreign language just can not happen in any meaningful way.

According to Ur (1998: 60) vocabulary can be defined, roughly, as the words people teach in the foreign language. It means vocabulary is written or spoken unit of language as symbol of idea in foreign language introduced to learners. If a teacher teaches new words in a foreign language, it means the teacher teaches vocabulary. Moreover, Allen (1983: 4) states that vocabulary is a fundamental component of second language proficiency, it is natural to expert that one of the primary goals of language learning is to know the meaning of the words.

From those statements above, it can be concluded that vocabulary is a stock of words which is used by someone to convey ideas and feeling, so that he or she can communicate with others in his or her environment. 
According to Arneson (2004), snakes and ladders game is an ancient Indian board game regarded today as a worldwide classic. It is played between two or more players on a game board having numbered, gridded squares. A number of "ladders" and "snakes" are pictured on the board, each connecting two specific board squares. The object of the game is to navigate one's game piece, according to die rolls, from the start (bottom square) to the finish (top square), helped or hindered by ladders and snakes respectively. The historic version had root in morality lessons, where a player's progression up the board represented a life journey complicated by virtues (ladders) and vices (snakes).

Similarly, Augustyn (2004: 480) states that snakes and ladders or chutes and ladders is a classic children board game. It is played between two or more players on a playing board with numbered grid squares. The square on the grid a number of ladders connecting two together, and a number of snakes or chutes also connecting squares together. The elements used for playing snakes and ladders are snakes and ladders board, a dice, question packs, and playing pieces or tokens.

In this research, the researcher implemented Snakes and Ladders game to improve the fifth grade students' vocabulary mastery. The teaching procedures to implement snakes and ladders game were as follows; firstly, the teacher prepared the snakes and ladders board, a dice, tokens, and question packs. Then, the teacher divided the students into 6 groups. After that, the teacher read the rules must be obeyed by each group. Every group started playing the game as their turn. The teacher gave 20 minutes for each group to play the game. When one group played the game, the others group had to pay attention to the game. Every player of the group took turn to throw a dice and moved his or her token along the squares. When the player moved, he or she had to read the vocabularies on the squares. After moving his or her token, the player took one of question packs then answered the question. The player would get 10 poin if the answer was correct and got 0 poin if wrong. The other groups should check whether the answer was right or wrong. If the player arrived on a square with ladder, he or she might go up the ladder. If the player arrived on a square with a snake's head, he or she might 
go down the snake. The game finished when a player of the group reached the 'finish' board.

By playing the snakes and ladders game, students could expand their vocabulary through the words on the squares. By reading the words on the squares, the students could improve their pronunciation and memorize the meaning of vocabularies. The students could also improve their spelling and their ability in using the words in the sentences correctly by answering the questions in the question packs while the game was played.

\section{RESEARCH METHOD}

The research was conducted in an elementary school in Karangmojo. This elementary school is located in Ngablak, Tasikmadu, Karanganyar. The research was conducted in two months, from Mei to June 2014. The subject of the research was the fifth grade of an elementary school in Karangmojo. There were 26 students in this class, 12 female students and 14 male students.

The researcher applied an action research. According to Nunan (1992: 229), action research is a form of self-reflective inquiry caried out by practitioners, aimed at solving problems, improving practice, or enhancing understanding. It is often collaborative. While Wallace (1998: 1) gives his definition of action research as the sytematic collection and analysis of data relating to the improvement of some aspect of professional practice.

Similarly, Mills (2000: 6) states that action research is systematic inquiry conducted by teacher, researchers, principles, school counselors, or other stakeholders in the teaching or learning environment to gather information about the ways that there particular school operate how they teach, and how well their students learn.

The technique of collecting the data was done by interview, observation, and test. The researcher did the interview to know the students' problems faced during the teaching and learning process. The observation was done by the researcher to know the activities, setting, and persons involved in the activities. The result of the observation was written in the form of field notes. 
In analyzing the data, the researcher used two method; qualitative and quantitative. Analyzing the data using qualitative method included assembling the data, coding the data, comparing the data, building interpretations of the data, and reporting the outcomes. To analyze the result of the tests, the reseacher used quantitative method. The resercher analyzed the students' mean score of pre-test and post-test to identify the improvement of the students' vocabulary mastery before and after the action.

\section{RESEARCH FINDING AND DISCUSSION}

After identifying the problems, the researcher conducted a pre-test. The pre-test was done before implementing the teaching learning processusing snakes and ladders game. The test was used to know the students' vocabulary mastery at the fifth grade of an elementary school in Karangmojo. The mean of the pre-test was 59.2. Based on the observation and pre-test result, the researcher identified that the students' vocabulary mastery was lowbecause it was below the passing grade (Kriteria Ketuntasan Minimal/KKM) for English lesson (70.0). Therefore, the researcher used snakes and ladders game as teaching technique to improve the students' vocabulary mastery and class atmosphere toward English lesson.

After finding the problems by the observation, pre-test, and using interview, the researcher made a plan to teach vocabulary in cycle 1 . She prepared materials of snakes and ladders game, lesson plan and relevant books. She planned three meetings in cycle 1 . Time for each meeting is 60 minutes. The researcher chose materials which are suitable for the students. In this cycle the researcher implemented the teaching technique using snakes and ladders game. She was doing the action based on the lesson plan.

After analyzing the observation result in the cycle one, the researcher did reflection in order to evaluate the teaching and learningprocess she did so far. She found the students' progress in mastering the vocabulary. Observation result showed that there were some improvements achieved by the students after doing the action. In cycle 1, the mean score of the students increased. It could be seen by comparing the result of the pre-test and post-test during the implementation of the 
action. The mean score of the post-test result done at the end of the cycle one was 69.1. It was better than the mean score of the pre-test which was done before the action, 59.2. Besides the improvement of students' vocabulary mastery, there were also some improvements in the class atmosphere. The students' interest toward the material increased.

Based on the result of the first cycle, the researcher realized that there were improvements of the students' vocabulary mastery, but the researcher still found some problems faced by the students. Some students still had difficulties in pronouncing the words and using the words in appropriate context of situation. Dealing with those problems in the first cycle, the researcher revised her plans.

To overcome the problems in Cycle 1, the researcher revised the plan that would be implemented in the next cycle, so that the problems would not occur anymore. The plan for the next cycle would be more focused on pronouncing the vocabulary and using the vocabulary in appropriate context of situation.

The action plan for Cycle 2 was arranged after reflecting the observation results in Cycle 1 in which the researcher found the weaknesses of Cycle 1. Just like planning the action for Cycle 1, there were some things that were done in planning the action for Cycle 2 such as sharing ideas with the collaborator, making lesson plan, revising the snakes and ladders elements, etc. From the researcher's observation, she knew that the students still had difficulties in pronouncing the words and using them in appropriate context of situation.

The test scores in cycle 2 showed the improvementresult. The mean score of the pre-test was 59.2, while the mean score of the post-test in cycle 1 was 69.1 and the mean score of the post-test incycle 2 was 77.6. In the second cycle, the using of snakes and ladders game made the vocabulary class ran very well. The classroom atmosphere was more alive and more fun because the students felt more confident with the success they had made. The students looked more involved in every activity and also ready for working either in group or individually.

In general two cycles which were implemented can overcome the vocabulary mastery problems in the researcher's class. The class atmosphere also 
improved. The improvement can be seen from the students' ability in understanding the meaning of words, pronouncing the words correctly, spelling the words correctly, and using the words in appropriate context of situation. Finally, each indicators can improved in cycle 2. The improvement of class atmosphere included; the students' interest toward the material increased, students were active during the lesson and could work in group and individually.

In discussion section, the researcher presents the discussion of research findings containing important points from the first cycle to the second cycle as the final reflection. The first point is the snakes and ladders game improve the students' vocabulary mastery. Previously, most of students had difficulty to memorize the meaning of vocabulary. By having snakes and ladders game, the students got an idea about their vocabulary. The observation on the effectiveness of snakes and ladders to improve the students' vocabulary mastery was on the students' ability of developing the idea into spoken and written tests. By answering the questions of the question packs during the game, the students had the guidelines to do the vocabulary test. Hadfield (1996:4) states that remembering new words is hard. Words are very slippery things. Games are one of effective techniques to practice new words.

By reading the vocabularies on the squares, the students practiced to use correct pronunciation. It made their pronunciation was improved. "Through games, students were encouraged to practice their ability in pronouncing and to recognize the new words " (Schmitt \& McCharty, 1997: 326). In snakes and ladders game, the students' vocabulary in the element of spelling improved when they answered the questions on the question packs. The question was about how to spell the words correctly. They also arranged jumbled letters into the correct spelling. Khan in Brumfit, Moon \&Tongue, 1995: 146) says that the specific language focus of games could be items of vocabulary or particular structures or functions. The language focus could be any one of the major skills of listening, speaking, reading and writing, with a narrower focus on spelling or pronunciation.

By applying snakes and ladders game, the teacher also trained the students in using the words in the appropriate context. McCallum (1980: ix) states that 
games focus students attention on spesific structures, grammatical patterns, and vocabulary items. By answering the questions on the question packs, the students trained to choose the appropriate vocabulary. Moreover, Schmitt and McCharty (1997: 326) state about "receptive and productive knowledge". Receptive knowledge is words that the learners recognize and understand when they occur in context, while productive knowledge relates toward which the learners understand, able to pronounce correctly and use constructively in speaking and writing. Therefore, the choice of words became more varied as they were trained to think creatively to choose the appropriate words based on the context of situation.

The second point is the snakes and ladders game improved the class atmosphere. The improvement was explained as follows. The students' interest toward the material increased. The students were more involved and more interested in the material presented by the teacher.As stated by Wright, et al (2006: 3), games help and encourage many learners to sustain their interest and work. The improvement of the students' interest could be seen when they enthused to be involved in the game. Their interest increased during the competition of games.

Snakes and ladders game provides more chances for students to actively develop themselves. It helps them better in participating during the class. McCallum (1980: ix) states that games can function as reinforcement, review, and enrichment. Games involve equal participation from both slow and fast learners, provide immediate feedback for the teacher, and ensure maximum students participation for a minimum of teacher preparation.

Snakes and ladders game helped the students in doing workgroup and independent activities. As stated by Philips (1997: 85), games in the language classroom help children to see learning English as enjoyable and rewarding. Playing games in the classroom develops the ability to cooperate, to compete, without being aggresive, and to be a good loser. Similarly, McCallum (1980: ix) addes that games contribute to an atmosphere of healthy competition, providing an outlet for creative use of natural language in a non-stressful situation. 


\section{CONCLUSION, IMPLICATION, AND SUGGESTION}

The findings of the results show the positive improvements in the students' vocabulary mastery and class atmosphere. In conclusion, the final discussion in the previous chapter can be drawn into two conclusions. Firstly, the result of the research showed that the use of snakes and ladders game improves the students' vocabulary mastery that covers; the students could understand the meaning of words, pronounce the words correctly, spell the vocabulary correctly, and use the words in appropriate context of situation. The improvement of vocabulary mastery can be seen from the test results. The mean score increased from cycle 1 to cycle 2 . The mean score of pre-test is, 59.2, the mean score of post-test in cycle 1 is 69.1 , and the mean score of post-test in cycle 2 is 77.6

Secondly, the implementation of snakes and ladders game in vocabulary mastery refines the class atmosphere. The improvements are indicated by the students' interest toward the material increased, the students'participation in class increased, and the students could work either in group or individually.

Based on the conclusion of all of the data in the research, there is improvement of the students' vocabulary mastery using games. There was a great result in improving the students' vocabulary mastery. The snakes and ladders game is in fact what the students need in their language learning. The students express their ideas freely, are more confident, improve or maintain their positive attitudes about themselves, school, peers, and academic abilities. With all of the strengths of snakes and ladders game, teacher can take the benefits that the snakes and ladders game can overcome the problems arising in class.

The illustration above implies that using snakes and ladders game in English class is strongly suggested. The teacher should use the snakes and ladders game in class to help her students to master the vocabulary.

Based on the previous experiences that the researcher got during the action research, the research could give suggestions for the teachers to select and present appropriate questions according to the students' level and need, socialize the objectiveness and techniques of snakes and ladders game before using them in the 
class, and actively observe the students during the implementation of snakes and ladders game.

For the students, it is suggested that the students to develop vocabulary mastery through his/her own efforts, actively participate in snakes and ladders game, learn a lot of vocabulary using different types of strategy. For other researchers, it is suggested that the other researchers continue the research by developing the aspects which has not been developed in this research. Last for the school, it is suggested to make a socialization of implementing snakes and ladders game to teach English especially in English class, provide adequate facilities to support the success of the teaching and learning process, and always motivate the school practitioners to develop their talent and profession in order that they can keep up with the growing education and technology for facing the global era. 


\section{REFERENCES}

Allen, V. F. (1983). Technique in Teaching Vocabulary. Oxford: Oxford University Press.

Arneson, Erick. (2004). Chutes and Ladders - Snakes and Ladders.http://boardgames.about.com/chutes_ladders.html. [May $2^{\text {nd }}$ 2014].

Augustyn, Frederick J. (2004). Dictionary of Toys and Game in America Popular Culture. Haworth Press

Brumfit, C., Moon, J., \& Tongue, R. (1995). Teaching English to Children from Practice to Principle. Harlow: Longman Press.

Hadfield, J. (1996). Elementary Communication Games. Harlow: Addison Wesley Longman Ltd.

Hatch, E and Brown, C. (1995). Vocabulary, Semantic, and Language Education.

Hornby, A.S. (1995). Oxford Advantaced Learner's Dictionary of Current English. Oxford: Oxford University Press.

McCallum, G. P. (1980). 101 Word Games. New York: Oxford University Press.

Mills, G. E. (2000). Action research: a guide for the teacher researcher. United States of America: Prentice Hall.

Nunan, David. (1998). Language Teaching Methodology: A textbook for Teacher. Great Britain: Prentice Hall.

Phillip, S. (1997). Young Learners. New York: Oxford University Press.

Schmitt, N., \& McCharty, M. (1997). Vocabulary: Description Acquisition and Pedagogy. Cambridge: Cambridge University Press.

Ur, P. (1998). A Course in Language Teaching. Australia: Cambridge University Press

Wallace, M. J. (1998). Action Research for Language Teachers. Cambridge: Cambridge University Press.

Wright, A., Betteridge, D., \& Buckby, M. (2006).Games for Language Learning. New York: Cambridge University Press. 